Rajić Milana*

UDK 159.922.76:376-053.4

PU "Radosno detinjstvo", Novi Sad

DOI: $10.19090 /$ gff.2017.2.339-359

Mihić Ivana,

Originalni naučni rad

Filozofski fakultet

Univerzitet u Novom Sadu

\title{
DOŽIVLJAJ KOMPETENTNOSTI I MOTIVACIJA VASPITAČA ZA RAD SA DECOM SA SMETNJAMA U RAZVOJU**
}

Iako je ideja inkluzije danas zaživela na svim nivoima obrazovanja, nalazi dosadašnjih istraživanja govore da zaposleni u obrazovnom sistemu dosledno pokazuju negativne stavove, nedovoljnu motivisanost, nesigurnost i procenjuju niskim lične kompetencije za rad. Cilj ovog istraživanja je bio da se ispita doživljaj kompetentnosti i motivacija za rad sa detetom sa smetnjama u razvoju, kao i efekat faktora koji potencijalno doprinose ovim varijablama. Uzorak je činilo 115 vaspitača iz predškolskih ustanova sa teritorije Vojvodine. Korišćeni instrument je sadržao vinjetu sa opisom deteta sa smetnjama u razvoju, na osnovu koje su vaspitači procenjivali očekivane probleme koje dete u vrtiću može imati, doživljaj kompetentnosti i motivaciju za rad sa detetom sa smetnjama u razvoju i doprinos inicijalnog obrazovanja i seminara stručnog usavršavanja. Rezultati ukazuju na to da stereotipna predstava o detetu i procena inicijalnog obrazovanja i seminara stručnog usavršavanja statistički značajno doprinose i doživljaju kompetentnosti i motivaciji za rad sa detetom sa smetnjama u razvoju. Rezultati su diskutovani u kontekstu razumevanja kompetentnosti vaspitača i usklađenosti zahteva inicijalnog obrazovanja i prakse.

Ključne reči: deca sa smetnjama u razvoju, inkluzija, vaspitači, kompetentnost, motivacija

\section{UVOD}

Danas je široko prihvaćena postavka da kvalitetno predškolsko vaspitanje i obrazovanje ima značajnu ulogu u bogaćenju ranog iskustva dece kroz pružanje prilika za istraživanje i saznavanje uz stimulisanje celovitog razvoja deteta, kao i kroz otvaranje mogućnosti za uključivanje u širu zajednicu (Klemenović, 2009). Profesionalne kompetencije zaposlenih u ustanovama koje realizuju programe predškolskog vaspitanja i obrazovanja se sve češće prepoznaju kao ključan faktor obezbeđivanja kvaliteta vaspitno-obrazovne prakse i podrške razvoju i saznavanju

\footnotetext{
*rajicmilana@gmail.com

** Istraživanje je nastalo u okviru projekta „Efekti egzistencijalne nesigurnosti na pojedinca i porodicu u Srbiji“, koji finansira Ministarstvo prosvete, nauke i tehnološkog razvoja (broj projekta 179022)
} 
dece tokom ranog i predškolskog uzrasta (Harvey, 2007). Diskurs kompetencija, definisan je u kontekstu stavova, vrednosti i veština vaspitača da realizuje vaspitnoobrazovni rad, a sem toga, u velikoj meri i oblikovan teorijskim znanjima koje vaspitači stiču u okviru svog inicijalnog obrazovanja i različitih vidova stručnog usavršavanja (Pavlović Breneselović, 2013). Implementacija inkluzivnog pristupa u obrazovanje na ranom uzrastu, koja podrazumeva uključivanje dece sa različitim rizičnim iskustvima razvoja u redovan vaspitno-obrazovni proces, pred vaspitače je stavila zahtev za većim angažovanjem u domenima stimulacije i praćenja razvoja dece, ali pre svega individualizacije rada i pristupa kako bi se deci pružilo jedinstveno iskustvo saznavanja $i$ istraživanja temeljeno na njegovim snagama $i$ interesovanjima. Kako bi odgovorio na postavljene zahteve, vaspitač bi trebalo da bude kompetentan profesionalac, dovoljno osetljiv na potrebe, iskustva i interesovanja svakog pojedinačnog deteta i otvoren za celoživotno učenje.

Kroz značajan broj istraživanja koja su se bavila kvalitetom inkluzivne prakse, u fokusu je bila perspektiva vaspitača - njihovo obrazovanje i prilike za stručno usavršavanje, te stavovi i uverenja o inkluzivnom obrazovanju i deci sa smetnjama u razvoju (Okvir za praćenje inkluzivnog obrazovanja u Srbiji, 2014). Iako identifikovane kao značajan prediktor kvaliteta vaspitno-obrazovne prakse (Sylva et al, 2002, prema Sheridan, 2007), profesionalne kompetencije vaspitača se neretko procenjuju kao nezadovoljavajuće, kada je u pitanju rad sa decom koja iz različitih razloga (materijalno stanje porodice, nisko obrazovanje roditelja, visok stres u porodici, niska funkcionalnost odraslih u starateljskoj ulozi, institucionalni smeštaj) rastu u uslovima zasićenim potencijalno nižim kvalitetom brige i odgovorom na razvojne potrebe. Najučestalija tema u ovoj oblasti i domen u kom su vaspitači kroz istraživanja pokazali najniži doživljaj kompetentnosti, spremnosti i motivacije za rad jeste rad sa decom sa smetnjama u razvoju, što se prepoznaje kao jedna od najvećih prepreka razvoja kvaliteta u radu sa ovom populacijom dece (Stančić i Stanisavljević-Petrović, 2013).

Niskom doživljaju kompetentnosti u praksi, potencijalno doprinosi i to što se inicijalno obrazovanje vaspitača još uvek temelji na dekontekstualizovanom učenju i podvojenosti teorije i prakse, sa primatom usvajanja teorijskih znanja nad razvijanjem kompetencija (Pavlović Breneselović, 2013), te ga i sami vaspitači procenjuju kao nedovoljno dobru pripremu za rad (Korać, 2015). Sem toga, na našem terenu se još uvek prepoznaje nezadovoljavajuća informisanost o inkluzivnom obrazovanju (Kovačević, 2015; Klemenović, 2014; Dedaj, 2015). Vaspitači u praksi često percipiraju da im u radu sa decom sa smetnjama u razvoju nedostaje stručna podrška (Sretenov, 2008). Manjak znanja i informisanosti u oblasti obrazovne i socijalne inkluzije, u značajnoj meri doprinosi razvoju 
negativnih stavova u vezi sa inkluzivnom praksom (Golder, Norwich \& Bayliss, 2005). Iako neka istraživanja u inostranstvu i kod nas ukazuju na pomak (Kopunović, 2009; Stančić i Stanisavljević Petrović, 2013), još uvek se u velikom procentu beleže ambivalentni ili negativni stavovi zaposlenih u obrazovanju prema inkluzivnom procesu (Cawley, Hayden, Cade \& Baker-Kroniczynski, 2002; Rezultati Istraživanja višestrukih pokazatelja položaja žena i dece u Srbiji 2014, Republički zavod za statistiku i UNICEF). Dominantno negativni stavovi vaspitača, u velikoj meri utiču na (ne)prihvatanje dece sa smetnjama u razvoju, što dalje može otežati njihovu socijalizaciju i puno uključivanje u vršnjačku grupu i učešće u životu vrtića (Vujačić, 2009). Ukoliko vaspitači, kao nosioci aktivnosti u inkluzivnoj praksi nisu dovoljno motivisani, imaju negativan stav, kvalitet realizacije inkluzije je upitan, čak i kad su potencijalno ispunjeni svi drugi uslovi u ustanovi uključujući i pozitivne stavove drugih učesnika procesa (Subban \& Sharma, 2006).

Implikacije negativnog stava i nedovoljne informisanosti i doživljaja spremnosti za rad sa decom sa smetnjama u razvoju mogu da se prepoznaju kroz neprihvatanje deteta (Akalin, Demir, Sucuoğlu, Bakkaloglu, \& Işen, 2014). Predškolska ustanova je mesto u kome dete treba da se oseća sigurno i prihvaćeno, kako bi bilo slobodno da istražuje, uz podršku vaspitača koji gradi odnose zasnovane na uključenosti, podršci i uvažavanju deteta, učestvuje ravnopravno u aktivnostima sa decom i usmeren je i osetljiv na potrebe, snage i interesovanja dece (Breneselović i Krnjaja, 2017). U tom smislu, veština vaspitača da stupa u interakcije sa decom, uspostavlja kvalitetne odnose, kako bi omogućio adekvatna iskustva dece u vrtiću, izdvaja se kao jedan od ključnih aspekata kompetentnosti. U planiranju podrške detetu sa smetnjama u razvoju, u praksi ustanova za predškolsko vaspitanje i obrazovanje još uvek dominiraju kompenzatorski i medicinski model (Mihić i Rajić, 2015), budući da se u planiranju polazi od onoga što dete ne može, što nema i šta nije u stanju da postigne bez podrške, umesto na snagama, mogućnostima i interesovanjima deteta. Takav pristup nosi rizik za neadekvatno uspostavljanje odnosa sa detetom, nisku senzitivnost, odnosno sposobnost vaspitača da primete i odgovore na potrebe deteta, podrže njegovo napredovanje, ali i nizak osećaj kompetentnosti za rad sa detetom (Mihić i Rajić, 2015).

Cilj ovog istraživanja bio je da se ispita doživljaj kompetentnosti i motivacija vaspitača za rad sa decom sa smetnjama u razvoju. Pri tom se pažnja posvećuje efektima koje na doživljaj kompetentnosti i motivaciju mogu imati očekivani problemi koje dete može imati u vrtiću, te procena doprinosa inicijalnog obrazovanja i seminara stručnog usavršavanja spremnosti za rad sa decom sa smetnjama u razvoju. 


\section{METOD}

Uzorak. U istraživanju je učestvovalo 115 vaspitača i medicinskih sestara, iz predškolskih ustanova sa teritorije Vojvodine ${ }^{1}$. Prosečan radni staž ispitanika u uzorku iznosio je oko 14 godina (Tabela 1.). Najkraća dužina radnog iskustva vaspitača u uzorku je bila 1 godinu, a najduže radno iskustvo 34 godina.

\section{Tabela 1.}

Dužina radnog iskustva ispitanika u ukupnom uzorku

\begin{tabular}{llllll}
\hline & N & Min & Max & M & SD \\
\hline Radno iskustvo & 109 & 1 & 34 & 14.05 & 8.62 \\
\hline
\end{tabular}

Na Grafiku 1. dati su deskriptivni pokazatelji koji govore o prethodnom iskustvu rada sa decom sa smetnjama u razvoju. Ukupno $72.3 \%$ ispitanika je, jednom ili više puta, imalo iskustvo rada sa decom sa smetnjama u razvoju, dok $27.3 \%$ nije nikada imalo priliku da radi sa ovom grupom dece. Takođe, ispitanici u ovom uzorku, u 73.4\% slučajeva, generalno decu sa smetnjama u razvoju navode kao grupu dece koja je najzahtevnija za rad u odnosu na druge grupe dece pod rizikom (deca iz diskriminisanih grupa, deca iz socijalne zaštite, deca sa iskustvima nasilja u porodici, deca iz niskostimulativnih porodica, deca iz porodica sa hronično obolelim članom).

Grafik 1.

Iskustvo u radu sa decom sa smetnjama u razvoju

\section{Iskustvo u radu sa decom sa smetnjama u razvoju}

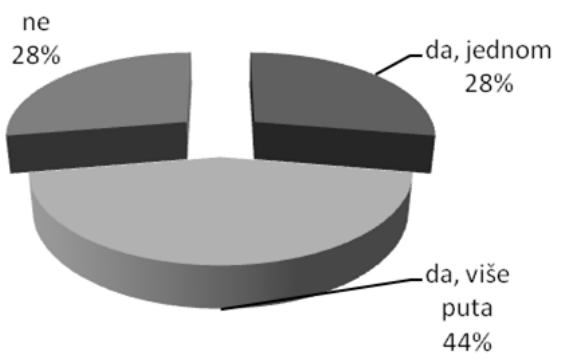

\footnotetext{
${ }^{1}$ PU "Radosno detinjstvo", Novi Sad, PU "Boško Buha", Inđija, PU "Jelica Stanivuković Šilja, Šid, PU "Radost", Novi Banovci, PU "Poletarac", Ruma, PU "Pčelica", Sremska Mitrovica
} 
Instrument za procenu kompetencija vaspitača za rad sa decom iz rizičnih grupa kreiran je u formi upitnika, za potrebe istraživanja u okviru projekta. Prvi deo upitnika se sastojao od vinjete ${ }^{2}$ sa opisom deteta sa smetnjama u razvoju, na osnovu koje su ispitanici procenjivali stepen $\mathrm{u}$ kom različiti faktori doprinose rizičnosti uslova života deteta iz primera, očekivanja u vezi sa problemima deteta u vrtiću (stereotipna predstava o detetu), sopstveni doživljaj kompetentnosti, motivaciju za rad sa konkretnim detetom, uslove u ustanovi za kvalitetan rad sa detetom i dobiti od vrtića za dete. Drugi deo upitnika se sastojao od procene dosadašnjih iskustava u radu sa decom sa smetnjama u razvoju, te procene doprinosa bazičnog obrazovanja i seminara stručnog usavršavanja spremnosti za rad sa detetom sa smetnjama u razvoju. U ovom radu, dat je prikaz podataka vezanih za procenu doživljaja kompetentnosti i motivacije za rad, očekivanja u vezi sa problemima koje dete sa smetnjama u razvoju može imati u vrtiću, te procenu doprinosa bazičnog obrazovanja i stručnog usavršavanja spremnosti za rad sa decom sa smetnjama u razvoju.

U vinjeti je opisan dečak sa smetnjom iz spektra autizma (Vedran ima 5 godina i smetnje iz autističnog spektra). Istraživanja dosledno ukazuju na to da je ovo grupa dece sa kojom u radu postoji najviše izazova (Dabrowska \& Pisula, 2010; Abbeduto et al., 2004).

Procedura. Stručni saradnici iz predškolskih ustanova su delili upitnike vaspitačima i stajali na raspolaganju u slučajevima kada je vaspitačima bila potrebna pomoć pri popunjavanju. U uputstvu je detaljno opisan cilj istraživanja i ispitanici su bili informisani o anonimnosti istraživanja. Svaki ispitanik mogao je da ima kontakt sa realizatorima istraživanja. Podaci za konkretnu predškolsku ustanovu su bili vraćeni onim ustanovama koje su podatke tražile radi daljeg planiranja i stručnog usavršavanja u oblasti rada sa decom iz rizičnih grupa.

\footnotetext{
${ }^{2}$ Vinjeta koja je deo upitnika sačinjena je na osnovu rezultata analize diskusija na fokus grupama sa stručnim saradnicima predškolskih ustanova (realizovanim na Susretima stručnih saradnika i saradnika predškolskih ustanova, 2015 godine) sa ciljem procene pripremljenosti vrtića na prihvat i rad sa decom sa iskustvima manje kvalitetne brige i stimulacije razvoja. Vinjete su kreirane tako da u svim obuhvaćenim grupama (deca sa smetnjama u razvoju, deca iz porodica sa hronično obolelim članom, deca iz sistema socijalne zaštite, deca iz romskih porodica, deca iz niskostimulativnih porodica, deca sa iskustvima nasilja u porodici) opisuju najzahtevnije dete za rad u datoj grupi, prema proceni stručnih saradnika iz predškolskih ustanova. Vinjete su omogućavale da i vaspitači koji nisu imali konktetno ili aktuelno iskustvo u radu sa decom sa smetnjama u razvoju mogu da daju svoje procene.
} 


\section{REZULTATI}

\section{Deskriptivni pokazatelji}

Stereotipna predstava o detetu. Vaspitači su procenjivali stepen u kom očekuju da se određeni problemi kod deteta u vrtiću pojave. Sve navedene teškoće u upitniku su moguće da se jave kod bilo kog deteta i ne moraju nužno biti povezane sa razvojnom smetnjom, niti su sve prisutne u istoj meri kod svakog deteta sa opisanom razvojnom smetnjom. Procenjivani su problemi u uspostavljanju kontakta sa vršnjacima i socijalnoj interakciji, problemi u oslanjanju na podršku i brigu vaspitača, problemi u mogućnosti obučavanja od strane vaspitača, problemi u emocionalnom reagovanju i regulaciji, problemi u saznavanju i zaključivanju i problemi u govoru.

Sve navedene potencijalne teškoće, vaspitači su, za dete iz vinjete, procenjivali iznad teorijskog proseka. Prosečne procene su se kretale od 3.08 do 3.57. Najviše procene uočavaju u domenu problema koji se odnose na uspostavljanje kontakta sa vršnjacima i socijalnu interakciju, dok je najniža prosečna procena dobijena u domenu problema u mogućnosti obučavanja od strane vaspitača (Tabela 2.).

\section{Tabela 2.}

Deskriptivni pokazatelji u domenu očekivanja u vezi sa problemima koje dete može imati $u$ vrtiću

\begin{tabular}{lccc}
\hline Kategorija & $\mathrm{N}$ & $\mathrm{M}$ & $\mathrm{SD}$ \\
\hline $\begin{array}{l}\text { Problemi u uspostavljanju kontakta sa } \\
\text { vršnjacima i socijalnoj interakciji }\end{array}$ & 115 & 3.57 & 1.20 \\
$\begin{array}{l}\text { Problemi u oslanjanju na podršku i brigu } \\
\text { vaspitača }\end{array}$ & 115 & 3.26 & 1.18 \\
$\begin{array}{l}\text { Problemi u mogućnosti obučavanja od strane } \\
\text { vaspitača }\end{array}$ & 115 & 3.08 & .86 \\
$\begin{array}{l}\text { Problemi u emocionalnom reagovanju i } \\
\text { regulaciji }\end{array}$ & 112 & 3.26 & 1.09 \\
$\begin{array}{l}\text { Problemi u saznavanju i zaključivanju } \\
\text { Problemi u govoru }\end{array}$ & 113 & 3.31 & 1.19 \\
\hline
\end{tabular}

Ne postoje statistički značajne razlike u proceni očekivanja problema koje dete sa smetnjama u razvoju može imati u vrtiću, između vaspitača koji nisu nikad, tokom radnog iskustva, imali prilike da rade sa decom sa smetnjama u razvoju, vaspitača koji su jednom imali priliku i vaspitača koji su više puta imali priliku da rade sa decom sa smetnjama u razvoju. 
Inicijalno obrazovanje i stručno usavršavanje. U Tabeli 3. dat je prikaz procena ispitanika o stepenu u kom smatraju da ih je bazično obrazovanje pripremilo za rad sa decom iz različitih rizičnih grupa. Kada je u pitanju doprinos inicijalnog obrazovanja spremnosti za rad sa decom sa smetnjama u razvoju, vaspitači su davali niže procene, nego u slučaju seminara stručnog usavršavanja.

Tabela 3.

Prikaz deskriptivnih pokazatelja u domenima doprinosa inicijalnog obrazovanja $i$ seminara stručnog usavršavanja spremnosti za rad sa decom sa smetnjama u razvoju

\begin{tabular}{lllllllll}
\hline Kategorija & 1 & 2. & 3 & 4 & 5 & Ukupno & M & SD \\
\hline Inicijalno & 33 & 21 & 33 & 13 & 7 & 107 & 2.44 & 1.23 \\
obrazovanje & $(30.8 \%)$ & $(19.6 \%)$ & $(30.8 \%)$ & $(12.1 \%)$ & $(6.5 \%)$ & & & \\
$\begin{array}{l}\text { Seminari } \\
\text { stručnog }\end{array}$ & $(10.3 \%)$ & 19 & 23 & 16 & 12 & 78 & 3.06 & 1.22 \\
usavršavanja & $(24.4 \%)$ & $(29.5 \%)$ & $(20.5 \%)$ & $(15.4 \%)$ & & & \\
\hline
\end{tabular}

Postoje statistički značajne pozitivne korelacije procene doprinosa inicijalnog obrazovanja i seminara stručnog usavršavanja spremnosti za rad sa detetom $i$ svih varijabli iz domena procene očekivanja u vezi sa problemima koje dete može imati u vrtiću, sem procene očekivanja problema u uspostavljanju vršnjačkih kontakta i socijalne interakcije i problema u oslanjanju na podršku i brigu vaspitača (Tabela 4.). Vaspitači koji doprinos inicijalnog obrazovanja i seminara stručnog usavršavanja spremnosti za rad procenjuju višim, imaju stereotipnu predstavu deteta sa smetnjama u razvoju koja je zasićena višim procenama svih očekivanih problema.

Tabela 4.

Interkorelacije varijabli iz domena očekivanja u vezi sa problemima koje dete može imati u vrtiću i doprinosa inicijalnog obrazovanja i seminara stručnog usavršavanja spremnosti za rad

\begin{tabular}{llllllllll}
\hline & 1 & 2 & 3 & 4 & 5 & 6 & 7 & 8
\end{tabular}

Problemi u uspostavljanju

$\begin{array}{lllllll}.611^{* * *} & -.076 & .024 & .013 & -.012 & .037 & .070\end{array}$

kontakta sa vršnjacima i

socijalnoj interakciji (1)

Problemi u oslanjanju na

$$
\begin{array}{llllllll}
.611^{* *} & 1 & -.120 & -.042 & -.074 & -.123 & -.076 & -.092
\end{array}
$$

podršku i brigu vaspitača (2)

Problemi u mogućnosti $-.076-.120$

$1 \quad .478^{* *} \quad .395^{* *} \quad .314^{* *} \quad .512^{* *} \quad .489^{* *}$

obučavanja od strane vaspitača 
(3)

\begin{tabular}{|c|c|c|c|c|c|c|c|c|}
\hline $\begin{array}{l}\text { Problemi u emocionalnom } \\
\text { reagovanju i regulaciji (4) }\end{array}$ & .024 & -.042 & $.478^{* * *}$ & 1 & $.802^{* * *}$ & $.646^{* *}$ & $.518^{* * *}$ & $.528^{* *}$ \\
\hline $\begin{array}{l}\text { Problemi u saznavanju i } \\
\text { zaključivanju (5) }\end{array}$ & .013 & -.074 & $.395^{* *}$ & $.802^{* *}$ & 1 & $.605^{* *}$ & $.557^{* *}$ & $.556^{* *}$ \\
\hline Problemi u govoru (6) & -.012 & -.123 & $.314^{* *}$ & $.646^{* *}$ & $.605^{* *}$ & 1 & $.568^{* *}$ & $.593^{* * *}$ \\
\hline $\begin{array}{l}\text { Doprinos inicijalnog } \\
\text { obrazovanja ( } 7)\end{array}$ & .037 & -.076 & $.512^{* * *}$ & $.518^{* *}$ & $.557^{* *}$ & $.568^{* *}$ & 1 & $.862^{* * *}$ \\
\hline $\begin{array}{l}\text { Doprinos seminara stručnog } \\
\text { usavršavanja ( } 8 \text { ) }\end{array}$ & .070 & -.092 & $.489^{* *}$ & $.528^{* *}$ & $.556^{* *}$ & $.593^{* *}$ & $.862^{* *}$ & 1 \\
\hline
\end{tabular}

Doživljaj kompetentntosti $i$ motivacije za rad. U Tabeli 5. je prikazana procena doživljaja kompetentnosti, motivacije za rad sa decom sa smetnjama u razvoju. Ispitanici u najmanjem broju slučajeva, procenjuju da se u potpunosti (5) osećaju kompetentno za rad, da su u potpunosti motivisani za rad sa detetom sa smetnjama u razvoju, iz vinjete procene su više nakrivljene ka nižim skorovima. $\mathrm{Na}$ skali od 1 (uopšte se ne osećam kompetentno) do 5 (u potpunosti se osećam kompetentno), prosečna procena doživljaja kompetentnosti za rad sa detetom sa smetnjama u razvoju je bila 2.89. Kada je u pitanju motivacija za rad sa detetom sa smetnjama u razvoju, prosečna procena je nešto viša i iznosila je 3.17.

\section{Tabela 5.}

Deskriptivni pokazatelji u domenima doživljaja kompetentnosti i motivacije za rad sa detetom sa smetnjama u razvoju

\begin{tabular}{lllllllll}
\hline Kategorija & 1 & 2 & 3 & 4 & 5 & Ukupno & M & SD \\
& & & & & & & & \\
\hline Doživljaj & 18 & 28 & 29 & 29 & 11 & 115 & 2.89 & 1.22 \\
kompetentnosti & $(15.7)$ & $(24.3)$ & $(25.2)$ & $(25.2)$ & $(9.6)$ & $(100.0)$ & & \\
Motivacija za & 16 & 13 & 37 & 34 & 15 & 115 & 3.17 & 1.21 \\
$\operatorname{rad}$ & $(13.9)$ & $(11.3)$ & $(32.2)$ & $(29.6)$ & $(13.0)$ & $(100.0)$ & & \\
\hline
\end{tabular}

$\mathrm{Ne}$ postoje statistički značajne razlike u doživljaju kompetentnosti i motivaciji za rad, između vaspitača koji su u dosadašnjem iskustvu imali priliku da rade sa detetom sa smetnjama više puta, jednom i onih koji nikada nisu imali prilike da rade sa detetom sa smetnjama u razvoju. 
Efekat varijabli iz domena očekivanih problema koje dete može imati u vrtiću $i$ procene inicijalnog obrazovanja i seminara stručnog usavršavanja na doživljaj kompetentnosti i motivaciju za rad

$\mathrm{U}$ cilju ispitivanja potencijalnih efekata procene očekivanja u vezi sa problemima koje dete sa smetnjama u razvoju može imati u vrtiću i procene doprinosa inicijalnog obrazovanja i seminara stručnog usavršavanja, na doživljaj kompetentnosti vaspitača i motivaciju za rad sa detetom sa smetnjama u razvoju, sprovedene su dve hijerarhijske regresione analize. U model regresione analize, za obe kriterijumske varijable (doživljaj kompetentnosti i motivacija za rad), u prvom koraku su unete varijable koje se tiču očekivanja u vezi sa problemima koje dete sa smetnjama u razvoju može imati u vrtiću, a u drugom koraku varijable koje se tiču procene doprinosa inicijalnog obrazovanja i seminara stručnog usavršavanja.

$\mathrm{U}$ Tabeli 6. dat je prikaz rezultata hijerarhijske regeresione analize, u slučaju doživljaja kompetentnosti. Dobijeni rezultati sugerišu da je model u celini statistički značajan, i varijablama u oba koraka, objašnjeno je oko $25 \%$ ukupne varijanse doživljaja kompetentnosti vaspitača. Varijable, dodate u drugom koraku (procene doprinosa inicijalnog obrazovanja i seminara stručnog usavršavanja), ne doprinose značajno promeni ukupne objašnjene varijanse.

Tabela 6.

Efekat procene očekivanih problema koje dete može imati u vrtiću na doživljaj kompetentnosti

\begin{tabular}{llcccc}
\hline $\begin{array}{l}\text { Zavisna } \\
\text { varijabla: } \\
\text { Doživljaj } \\
\text { kompetentnosti }\end{array}$ & $\mathrm{R}$ & $\mathrm{R}$ Square & $\begin{array}{c}\text { R Square } \\
\text { Change }\end{array}$ & $\mathrm{F}$ & F Change \\
\hline Model 1 & .427 & .182 & .182 & $2.526^{*}$ & $2.526^{*}$ \\
Model 2 & .496 & .246 & .064 & $2.689^{*}$ & 2.780 \\
\hline
\end{tabular}

Model 1- domen očekivanja u vezi sa problemima koje dete sa smetnjama u razvoju može imati u vrtiću

Model 2- domen doprinosa inicijalnog obrazovanja i seminara stručnog usavršavanja ${ }^{*} \mathrm{p}<.05$

Iako je model u celosti statistički značajan, pojedinačni doprinosi varijabli iz domena očekivanih problema koje dete može imati u vrtiću i iz domena doprinosa inicijalnog obrazovanja i seminara stručnog usavršavanja spremnosti za rad sa detetom sa smetnjama u razvoju, nisu statistički značajni (Tabela 7.). 
Tabela 7.

Doprinos pojedinačnih varijabli značajnosti regresionih modela

\begin{tabular}{|c|c|c|c|c|}
\hline Zavisna varijabla: Doživljaj kompetentnosti & B & SE B & $\beta$ & $\mathrm{p}$ \\
\hline \multicolumn{5}{|l|}{ Model 1} \\
\hline $\begin{array}{l}\text { Problemi u uspostavljanju kontakta sa } \\
\text { vršnjacima i socijalnoj interakciji }\end{array}$ & -.138 & .136 & -.139 & $>.05$ \\
\hline $\begin{array}{l}\text { Problemi u oslanjanju na podršku i brigu } \\
\text { vaspitača }\end{array}$ & -.193 & .168 & -.195 & $>.05$ \\
\hline $\begin{array}{l}\text { Problemi u mogućnosti obučavanja od strane } \\
\text { vaspitača }\end{array}$ & -.117 & .202 & -.079 & $>.05$ \\
\hline $\begin{array}{l}\text { Problemi u emocionalnom reagovanju i } \\
\text { regulaciji }\end{array}$ & -.083 & .178 & -.078 & $>.05$ \\
\hline Problemi u saznavanju i zaključivanju & .131 & .220 & .125 & $>.05$ \\
\hline Problemi u govoru & -.169 & .210 & -.158 & $>.05$ \\
\hline \multicolumn{5}{|l|}{ Model 2} \\
\hline $\begin{array}{l}\text { Problemi u uspostavljanju kontakta sa } \\
\text { vršnjacima i socijalnoj interakciji }\end{array}$ & -.225 & .140 & -.227 & $>.05$ \\
\hline $\begin{array}{l}\text { Problemi u oslanjanju na podršku i brigu } \\
\text { vaspitača }\end{array}$ & -.121 & .166 & -.122 & $>.05$ \\
\hline $\begin{array}{l}\text { Problemi u mogućnosti obučavanja od } \\
\text { strane vaspitača }\end{array}$ & -.119 & .198 & -.080 & $>.05$ \\
\hline $\begin{array}{l}\text { Problemi u emocionalnom reagovanju i } \\
\text { regulaciji }\end{array}$ & -.206 & .181 & -.194 & $>.05$ \\
\hline Problemi u saznavanju i zaključivanju & .154 & .215 & .147 & $>.05$ \\
\hline Problemi u govoru & -.187 & .204 & -.174 & $>.05$ \\
\hline Doprinos inicijalnog obrazovanja & -.234 & .146 & -.236 & $>.05$ \\
\hline Doprinos seminara stručnog usavršavanja & -.078 & .143 & -.075 & $>.05$ \\
\hline
\end{tabular}

U Tabeli 8., dat je prikaz rezultata hijerarhijske regresione analize, u slučaju motivacije za rad kao zavisne varijable. Dobijeni rezultati ukazuju na to da je model u celosti značajan i da je varijablama u oba koraka objašnjeno oko $25 \%$ ukupne varijanse motivacije za rad sa detetom sa smetnjama u razvoju. 
Tabela 8.

Efekat procene očekivanja problema koje dete može imati u vrtiću na motivaciju za rad

\begin{tabular}{lccccc}
\hline $\begin{array}{l}\text { Zavisna } \\
\text { varijabla: } \\
\begin{array}{l}\text { Motivacija za } \\
\text { rad }\end{array}\end{array}$ & $\mathrm{R}$ & $\mathrm{R}$ Square & $\begin{array}{c}\text { R Square } \\
\text { Change }\end{array}$ & $\mathrm{F}$ & F Change \\
\hline Model 1 & .455 & .207 & .207 & $2.960^{*}$ & 2.960 \\
Model 2 & .502 & .252 & .045 & $2.782^{*}$ & 1.989 \\
\hline
\end{tabular}

Model 1- domen očekivanja u vezi sa problemima koje dete sa smetnjama u razvoju može imati u vrtiću

Model 2- domen doprinosa inicijalnog obrazovanja i seminara stručnog usavršavanja $* \mathrm{p}<.05$

Kada je u pitanju doprinos pojedinačnih prediktora iz seta varijabli koje se odnose na procenu očekivanih problema koje dete može imati u vrtiću i seta koji se odnosi na procenu doprinosa inicijalnog obrazovanja i seminara stručnog usavršavanja spremnosti za rad sa detetom, nisu dobijeni statistički značajni efekti (Tabela 9.).

Tabela 9.

Doprinos pojedinačnih varijabli značajnosti regresionih modela

\begin{tabular}{lllll}
\hline Zavisna varijabla: Doživljaj kompetentnosti & B & SE B & $\beta$ & p \\
\hline $\begin{array}{l}\text { Model 1 } \\
\quad \begin{array}{l}\text { Problemi u uspostavljanju kontakta sa } \\
\text { vršnjacima i socijalnoj interakciji }\end{array}\end{array}$ & -.149 & .136 & -.148 & $>.05$ \\
$\quad \begin{array}{l}\text { Problemi u oslanjanju na podršku i brigu } \\
\quad \text { vaspitača }\end{array}$ & -.072 & .168 & -.071 & $>.05$ \\
$\quad \begin{array}{l}\text { Problemi u mogućnosti obučavanja od strane } \\
\quad \text { vaspitača }\end{array}$ & -.128 & .202 & -.085 & $>.05$ \\
$\quad \begin{array}{l}\text { Problemi u emocionalnom reagovanju i } \\
\quad \text { regulaciji }\end{array}$ & -.261 & .178 & -.242 & $>.05$ \\
$\quad \begin{array}{l}\text { Problemi u saznavanju i zaključivanju } \\
\quad \text { Problemi u govoru }\end{array}$ & -.029 & .220 & -.028 & $>.05$ \\
& .007 & .210 & .006 & $>.05$
\end{tabular}

\section{Model 2}

Problemi u uspostavljanju kontakta sa

vršnjacima i socijalnoj interakciji

Problemi u oslanjanju na podršku i brigu

vaspitača

Problemi u mogućnosti obučavanja od strane

vaspitača

Problemi u emocionalnom reagovanju i

$\begin{array}{llll}-.216 & .141 & -.215 & >.05\end{array}$

$\begin{array}{llll}-.011 & .168 & -.010 & >.05\end{array}$

$\begin{array}{llll}-.138 & .201 & -.091 & >.05\end{array}$

$\begin{array}{llll}-.365 & .183 & -.339 & >.05\end{array}$ 
regulaciji

Problemi u saznavanju i zaključivanju

$\begin{array}{llll}-.009 & .217 & -.008 & >.05\end{array}$

Problemi u govoru

$\begin{array}{llll}-.008 & .007 & -.008 & >.05\end{array}$

Doprinos inicijalnog obrazovanja

$-.167$

.148

$-.166>.05$

Doprinos seminara stručnog usavršavanja

$-.107$

.144

$-.100>.05$

\section{DISKUSIJA}

Aktuelni trend uključivanja dece iz rizičnih grupa u predškolsko vaspitanje i obrazovanje, sa sobom je doneo i sve veće interesovanje istraživača u oblasti definisanja neophodnih kompetencija vaspitača za rad sa ovim grupama dece, analize aktuelnog stanja i načina daljeg građenja kompetencija. Dosadašnja istraživanja koja su se bavila percepcijom inkluzije od strane vaspitača, ukazala su na nisku motivaciju vaspitača, doživljaj nedovoljne informisanosti i kompetentnosti za rad, kao i prisustvo negativnih stavova i socijalne distance, posebno kada su u pitanju deca sa smetnjama u razvoju (Stančić i Stanisavljević-Petrović, 2013; Kovačević, 2015; Klemenović, 2014; Dedaj, 2015; Cawley et al., 2002). Kako bi se pružio doprinos razumevanju kompetentnosti i motivacije vaspitača za rad sa decom sa smetnjama u razvoju, ovo istraživanje je imalo za cilj da ispita procenu sopstvenog doživljaja kompetentnosti i motivacije za rad, te da se ispitaju faktori koji potencijalno doprinose doživljaju kompetentnosti i motivaciji za rad sa detetom sa smetnjama u razvoju - očekivanja u vezi sa problemima koje dete može imati u vrtiću, inicijalno obrazovanje i seminari stručnog usavršavanja. Rezultati dobijeni istraživanjem ukazuju na nizak doživljaj kompetentnosti i motivacije, relativno nisku procenu doprinosa inicijalnog obrazovanja i seminara stručnog usavršavanja, ali i na negativnu stereotipnu predstavu deteta sa smetnjama u razvoju. Očekivani problemi, kao i procena doprinosa inicijalnog obrazovanja i seminara stručnog usavršavanja, imaju značajne efekte na procenjeni doživljaj kompetentnosti i motivaciju za rad sa detetom.

Kroz očekivanja u vezi sa problemima koje dete može imati u vrtiću, kod vaspitača je procenjivana stereotipna predstava o detetu sa smetnjama u razvoju (Nosek, Greenwald \& Banaji, 2007; De Houwer, 2006). Dobijeni rezultati su ukazali na to da su vaspitači sve navedene probleme (problemi u uspostavljanju kontakta sa vršnjacima i socijalnoj interakciji, problemi u oslanjanju na podršku i brigu vaspitača, problemi u mogućnosti obučavanja od strane vaspitača, problemi u emocionalnom reagovanju i regulaciji, problemi u saznavanju i zaključivanju i problemi u govoru), procenjivali relativno visokim. Ta slika je ista bez obzira na 
prethodno iskustvo rada sa detetom sa smetnjama u razvoju. Vaspitači, s jedne strane najmanje očekuju probleme u domenu obučavanja deteta, a s druge strane najviše u domenu uspostavljanja kontakta sa vršnjacima i socijalnoj interakciji, putem koje se zapravo obučavanje, odnosno celokupan vaspitno-obrazovni rad u vrtiću odvija. Prethodna istraživanja kod nas, potkrepljuju ovaj nalaz i takođe beleže prisustvo negativnih stavova i predrasuda zaposlenih u obrazovanju prema deci sa smetnjama u razvoju generalno (Stanisavljevnić-Petrović i Stančić, 2010; Veljić, 2010).

Kod prosvetnih radnika je često prisutno uverenje da inkluzija nije potrebna ili da u uslovima u kojima rade ne postoje uslovi za kvalitetnu realizaciju inkluzivne prakse (Stanisavljević-Petrović i Stančić, 2010). Ovo uverenje prati osećaj nedovoljne kompetentnosti za rad sa decom sa smetnjama u razvoju, strepnja kako će prevazići izazove koje inkluzija nosi, kao i doživljaj da im stručna podrška izostaje (Rajović i Jovanović, 2010; Stanisavljevnić-Petrović i Stančić, 2010; Stanković-Đorđević, 2007; Vujačić, 2009). Uporedo sa navedenim, oni izveštavaju i o mnogo višem intenzitetu profesionalnog stresa (Brunsting, Sreckovic \& Lane, 2014). Iako su kroz ranija istraživanja, zaposleni u obrazovanju navodili svoje lično iskustvo stečeno radom kao važan izvor kompetencija i veština za rad sa decom sa smetnjama u razvoju (Korać, 2014), na ovom uzorku ta pravilnost nije uočena.

Jedna od pretpostavki zbog čega su vaspitači relativno visoko procenjivali probleme koje dete može imati u vrtiću jeste i ta da vinjeta, u odnosu na koju su procenjivali pomenute domene, sadrži opis deteta sa smetnjama iz spektra autizma, koje spade u grupu dece sa kojom u radu postoji najviše izazova (Dabrowska \& Pisula, 2010, Abbeduto et al., 2004). Kroz istraživanja se dosledno pokazuje da u odnosu na decu sa drugim razvojnim smetnjama, deca sa smetnjama iz spektra autizma manifestuju značajno više problema u ponašanju (Dumas, Wolf, Fisman, Culligan, 2009), a vaspitači u kontekstu rada sa ovom grupom dece, izveštavaju o zabrinutosti i strahu (Tomić i Milić, 2014). Istraživanja u radu sa detetom sa smetnjama iz spektra autizma, beleže dosledno negativne stavove zaposlenih $\mathrm{u}$ obrazovanju i visok profesionalni stres (Gregor \& Campbell, 2001; Lecavalier, Leone \& Wiltz, 2006), ali, s druge strane i manje problema u ponašanju deteta kada vaspitač odnos sa detetom percipira na pozitivan način (Robertson, Chamberlain \& Kasari, 2003). U daljim istraživanjima bi, zato, trebalo uzeti u obzir i potencijalnu razliku u mogućnosti prihvatanja dece sa drugim razvojnim smetnjama.

Procene doprinosa inicijalnog obrazovanja i seminara stručnog usavršavanja su u domenu prosečnih vrednosti, s tim da su vaspitači nešto više procene davali u slučaju seminara stručnog usavršavanja. Niske procene doprinosa inicijalnog obrazovanja spremnosti za rad su u skladu sa ranijim nalazima koji 
dosledno beleže da zaposleni u obrazovanju svoje obrazovanje procenili kao deklarativno, kom nedostaje funkcionalno pedagoško, psihološko i metodičko znanje (Korać, 2014). Autori koji su se bavili analizom inicijalnog obrazovanja vaspitača, kao osnovne nedostatke izdvojili su: tradicionalni pristup koncipiranju nastavnog plana i programa koji nije usmeren na celovit pristup detetu i koji podrazumeva organizaciju vaspitno-obrazovnog rada sa decom kroz aktivnosti $u$ skladu sa aspektima razvoja, zatim ex catedra pristup studentima koji ne podstiče na aktivno učešće, komunikaciju i istraživanje studenata (Stojanović, 2009). To potencijalno ukazuje na jaz između očekivanja koja se stavljaju pred buduće vaspitače - akumulacija delimičnih, fragmentisanih i izolovanih znanja, i očekivanja od vaspitača u praksi, koja su više usmerena na celovit pristup detetu, vrednosti vaspitača i praktične veštine. Studenti, budući vaspitači, u odnosu na vaspitače u praksi, doprinos inicijalnog obrazovanja spremnosti za rad sa decom sa smetnjama u razvoju takođe procenjuju višim (Radaković, Rajić, Mihić i Mirković, 2016). Jedan pogled na ovu pojavu je da studenti potencijalno svom budućem poslu pristupaju sa nedovoljnim znanjem o tome šta su zahtevi u praksi i sa određenom dozom entuzijazma i samouverenosti jer su uspešno ispunjavali zahteve tokom studija- koji su bili indikatori njihove kompetentnosti. Postavlja se pitanje u kojoj meri se studenti zapravo upućuju na vrednosti socijalne i obrazovne inkluzije, a u kojoj meri se od njih zahteva samo znanje o smetnjama u razvoju i metodama rada sa decom sa različitim smetnjama u razvoju (Sakač i Marić, 2016).

Kada su u pitanju seminari stručnog usavršavanja, istraživanja pokazuju da vaspitači u velikom broju slučajeva navode da su zadovoljni ponudom akreditovanih programa iz oblasti inkluzivnog obrazovanja, iako najveći broj njih navodi da je potrebno obezbediti veći broj i veću dostupnost programa, te da se oni više baziraju na praktičnoj primeni (Korać, 2015). Uvidom u spisak i sadržaj akreditovanih seminara, ponuđenih od strane Zavoda za unapređenje obrazovanja i vaspitanja, uočava se da se aktuelno najviše nude seminari koji se tiču rada sa decom sa smetnjama u razvoju (ZUOV- Katalog programa stalog stručnog usavršavanja nastavnika, vaspitača i stručnih saradnika za školsku 2016/2017. i 2017/2018.godinu). Dominantne teme ovih seminara su podrška individualizaciji rada sa decom sa smetnjama u razvoju, sa ciljem edukacije u vezi sa razvojnom smetnjom (simptomima i očekivanim problemima), planiranjem rada i načinima stimulacije razvoja (kompenzativni pristup), dok je vrlo malo usmeravanja na perspektivu prava deteta i celovitog razvoja, pristupa usmerenog na snage i interesovanja deteta. Istovremeno, istraživanja pokazuju da tek $25 \%$ vaspitača pohađa i te dostupne seminare stručnog usavršavanja (Klemenović, 2014), i da na nivo motivacije za daljim profesionalnim usavršavanjem iz oblasti inkluzije ne utiče 
značajno svakodnevno iskustvo u radu sa ovom decom (Đermanov, Đukić, Kosanović i Soldatović, 2013). Na osnovu ranijih, ali i na osnovu nalaza ovog istraživanja, kao potreba se uočava veća usmerenost na razvijanje praktičnih veština (Korać, 2014), podizanje svesti po pitanju vrednosti inkluzije, humanističkog pristupa i pristupa usmerenog na prava i snage deteta, što bi vodilo osnaživanju vaspitača u smeru većeg prihvatanja dece sa smetnjama u razvoju i u smeru drugačijeg razumevanja njihove uloge $u$ inkluzivnom procesu.

Kako bi se ispitalo u kojoj meri stereotipna predstava o detetu sa smetnjama u razvoju i procena doprinosa inicijalnog obrazovanja i seminara stručnog usavršavanja, oblikuje lični doživljaj kompetentnosti i motivaciju za rad sa decom sa smetnjama u razvoju kod vaspitača, sprovedene su dve hijerarhijske regresione analize. I kada je u pitanju doživljaj kompetentnosti i kada je u pitanju motivacija za rad sa detetom sa smetnjama u razvoju, modeli su u celosti značajni. Obe varijable (i motivacija i kompetentnost) su u najvećoj meri bile objašnjena prvim setom prediktora, koji su činile varijable vezane za stereotipnu predstavu o detetu, što ukazuje na njenu važnost. Negativna stereotipna predstava o detetu doprinosi manjem doživljaju kompetentnosti i nižoj motivaciji za rad sa detetom sa smetnjama u razvoju. Vaspitači koji visoko procenjuju svoja očekivanja u vezi sa problemima koje dete može imati u vrtiću imaju i tendenciju da visoko procenjuju i doprinos inicijalnog obrazovanja i seminara stručnog usavršavanja spremnosti za rad sa decom sa smetnjama u razvoju. Ova pravilnost otvara pitanje kvaliteta inicijalnog obrazovanja i stručnog usavršavanja, ali upravo te visoke interkorelacije prediktora mogu biti razlog izostanka statistički značajnih samostalnih doprinosa prediktora objašnjenju ukupne varijanse doživljaja kompetentnosti i motivacije za rad.

Podaci iz ovog istraživanja pozivaju na kontinuitet i obuhvatniji pristup praćenju kvaliteta inkluzivnog obrazovanja i činilaca koji mu doprinose. U narednim istraživanjima trebalo bi temi pristupiti obuhvatnijim merama kompetencije vaspitača- dakle ne samo samoprocenom jednoajtemskom merom, nego nekim drugim, posmatračkim merama kompetentnosti vaspitača u konkretnom radu. Jednako tako, potrebno je i preciznije i detaljnije razraditi i operacionalizovati varijablu doprinos inicijalnog obrazovanja ili stručnog usavršavanja, uz kontrolu podataka o temama i ciljevima različitih oblika usavršavanja koje su vaspitači prošli. Takođe, značajno je uzorak ujednačiti po iskustvu u radu sa decom sa smetnjama u razvoju kako bi se mogle ispitati razlike u ispitivanim varijablama, a takođe i kontrolisati kvalitet i okolnosti tog iskustva (npr. podrška vaspitaču, kvalitet odnosa sa detetom, ishodi po dete i sl.). 
Kompetentnost vaspitača uglavnom obuhvata određena teorijska znanja o razvoju dece, veštine vođenja grupe dece, komunikacijske veštine, poznavanje tehnika podučavanja, didaktičko-metodička znanja, veštine savetodavnog rada, spremnost na timski rad i celoživotno učenje (Bouillet, 2010). Kod nas je u predškolskom sistemu vaspitanja i obrazovanja još uvek u značajnoj meri prisutan medicinski model, što nužno definiše ulogu vaspitača kao nekog ko uočava nedostatke i teškoće $u$ detetovom razvoju, te odgovara na njih na način koji će detetu omogućiti da dostigne razvojno adekvatan cilj i približi se veštinama $i$ kapacitetima opisanim normom za određeni uzrast. U tim terminima, napredovanja deteta, se meri i kompetentnost vaspitača. Savremeni koncept kompetentnosti vaspitača, s druge strane, podrazumeva usmerenost na podršku detetu u istraživanju, podsticanje uključivanja deteta u aktivnosti, zasnovano na detetovim snagama i interesovanjima, uvažavajući detetova ranija iskustva i kulturni kontekst iz kog dete potiče (Breneselović i Krnjaja, 2017). Društvo, odnosno sistem, bi trebalo da podupire i gradi kompetentnost vaspitača u radu sa svom decom, kroz građenje intrinzične motivisanosti, temeljene na usmerenju na prava i snage deteta, znanja i veština za rad sa decom, kroz razne oblike usavršavanja i razmene iskustava među praktičarima. Sličnim putem može da se promeni i stereotipna predstava o detetu sa smetnjama u razvoju i ulozi vaspitača u inkluzivnom procesu, ukoliko se fokus više stavi na motivaciju, na stavove vaspitača, na usklađivanje inicijalnog obrazovanja i dostupnih seminara stručnog usavršavanja sa realnim potrebama u praksi, kako bi se praktičari osnažili i senzibilisali, i generalno, na drugačije razumevanje uloge vrtića i vaspitača u životu deteta i porodice. Samo pomeranje fokusa sa nedostataka na snage deteta, $u$ velikoj meri može da doprinese promenama u motivisanosti i doživljaju kompetentnosti vaspitača. Da bi inkluzivno obrazovanje zaista zaživelo, neophodno je vratiti se na osnovnu pretpostavku- sistem treba da se promeni i prilagodi detetu, a ne obrnuto. 
Rajić Milana, Mihić Ivana

\title{
SENSE OF COMPETENCE AND MOTIVATION OF PRESCHOOL TEACHERS FOR WORK WITH CHILDREN WITH DISABILITIES
}

\begin{abstract}
Summary
Enhancing early education quality has become a priority in the field of early childhood development, in the past decade. Much research has been implemented in order to investigate the factors contributing to the programme quality. Some of the research was aimed to investigate teachers' perspective on inclusion of children with disabilities, as they play a central role in providing quality. The research often shows that teachers don't feel confident enough, have low self competence, low motivation for work and negative attitudes towards children with disabilities. The aim of this study was to investigate the sense of competence, motivation for working with children with disabilities and the factors contributing to these variables - expectances about the problems a child may have at preschool and the contribution of the initial education and training seminars to their readiness for work with children with disabilities. The sample consisted of 115 preschool teachers, from Vojvodina. The instrument was developed for the purpose of a broader research. It contained a vignette, with the description of the child with disability, in relation to which the participants assessed (1) the sense of competence and motivation for working with child with disability, (2) the expected problems that a child may have at preschool - the problems in establishing contacts with peers and social interaction, relying on the educator's support and care, the problems in perceiving the teacher as an educator, in emotional response and regulation, and the problems in cognitive and speech development, (3) the contribution of initial education and training seminars to readiness for work with children with disabilities. In order to address the research questions, we conducted two hierarchical multiple regression analyses. In the first, the dependent variable was the sense of competence; in the second, it was motivation for work. In both models, the first set of predictors contained variables related to the expected problems at preschool, and the second set contained variables related to contribution of the initial education and training seminars to readiness for work with children with disabilities. The results have shown that the two sets of predictors significantly contributed to explanation of the sense of competence and motivation for working with children with disabilities, although there was no contribution of individual predictors. The results suggest that preschool teachers have the tendency to form stereotypical presentation of children with disabilities, which can lead to lower motivation and sense of competence in work with them. The results were also discussed in relation to the quality of formal and informal education provided to preschool teachers.
\end{abstract}

Key words: children with disabilities, inclusion, preschool teachers, sense of competence, motivation 


\section{LITERATURA}

Abbeduto, L., Seltzer, M. M., Shattuck, P., Krauss, M. W., Orsmond, G., \& Murphy, M. M. (2004). Psychological well-being and coping in mothers of youths with autism, down syndrome, orfragile X syndrome. American Journal on Mental Retardation, 109(3), 237-254.

Akalin, S., Demir, Ş., Sucuoğlu, B., Bakkaoglu, H., \& Işcen, F. (2014). The needs of inclusive preschool teachers about inclusive practices. Eurasian Journal of Educational Research, 14(2), 39-60.

Bouillet, D. (2010), Izazovi integriranog odgoja i obrazovanja. Zagreb: Školska knjiga.

Breneselović, D., Krnjaja, Ž. (2017). Kaleidoskop: osnove diversifikovanih programa. Beograd: Institut za pedagogiju i andragogiju.

Brunsting, N. C., Sreckovic, M. A., \& Lane, K. L. (2014). Special education teacher burnout: A synthesis of research from 1979 to 2013. Education and treatment of children, 37(4), 681-711.

Cawley, J.F., Hayden, S., Cade, E., \& Baker-Kroczynski, S. (2002). Including students with disabilities into the general education science classroom. Exceptional Children, 68, 423-435.

Clements, M., \& Barnett, D. (2002). Parenting and attachment among toddlers with congenital anomalies: Examining the Strange Situation and attachment Qsort. Infant mental health journal, 23(6), 625-642.

Dabrowska, A., \& Pisula, E. (2010). Parenting stress and coping styles in mothers and fathers of pre-school children with autism and Down syndrome.Journal of Intellectual Disability Research, 54(3), 266-280.

Dedaj, M. (2015). Podrška u realizaciji inkluzivnog obrazovanja iz perspective vaspitača i učitelja. Usmeno saopštenje na 6. Međunarodnoj naučnoj konferenciji „Inkluzija u predškolskoj ustanovi i osnovnoj školi“, Sremska Mitrovica, Srbija.

De Houwer, J. (2006). What are implicit measures and why are we using them. In: R.W. Wiers \& A.W. Stacy (Eds.) The handbook of implicit cognition and addiction. London: Sage Publications (pp. 11-28).

Dumas, J. E., Wolf, L. C., Fisman, S. N., \& Culligan, A. (1991). Parenting stress, child behavior problems, and dysphoria in parents of children with autism, Down syndrome, behavior disorders, and normal development. Exceptionality, 2, 97-110.

Đermanov, M., Đukić, M., Kosanović, M. i Soldatović, K. (2013). Struktura i korelati motivacije vaspitača za profesionalni razvoj u oblasti inkluzije. U 
M., Đukić (Ur) Inkluzivno obrazovanje: razvojni pravci i perspektive. Novi Sad: Filozofski fakultet.

Golder, G., Norwich, B., \& Bayliss, P. (2005). Preparing teachers to teach pupils with special educational needs in more inclusive schools: evaluating a PGCE development. British Journal of Special Education, 32(2), 92-99.

Gregor, E. M., \& Campbell, E. (2001). The attitudes of teachers in Scotland to the integration of children with autism into mainstream schools. Autism, 5(2), 189-207.

Harvey, L. (2007). Epistemology of quality. Perspectives in Education, 25(3), 1-13. Howe, D. (2006). Disabled children, parent-child interaction and attachment.Child \& family social work, 11(2), 95-106.

Istraživanje višestrukih pokazatelja položaja žena $\mathrm{i}$ dece $\mathrm{u}$ romskim naseljima $\mathrm{u}$ Srbiji, 2014, Glavni nalazi. Beograd: Republički zavod za statistiku i UNICEF

Klemenović, J. (2009): SAVREMENI PREDŠKOLSKI PROGRAMI, Novi Sad: Savez pedagoških društava Vojvodine, Vršac: Visoka škola strukovnih studija za obrazovanje vaspitača «Mihailo Palov». 207.str. ISBN 978-8684367-50-3; COBISS. SR-ID 244120071.

Klemenović, J. (2014). Spremnost za školu u inkluzivnom kontekstu, Novi Sad : Filozofski fakultet u Novom Sadu. ISBN:978-86-6065-291-3.

Kopunović, D. (2009). Stavovi vaspitača prema inkluzivnom programu u predškolskim ustanovama. Neobjavljena magistarska teza. Novi Sad: Filozofski fakultet.

Korać, I. (2014). Kompetencije nastavnika za inkluzivno obrazovanje, Usmeno saopštenje na V Međunarodna naučna konferencija "Inkluzija u predškolskoj ustanovi i osnovnoj školi, Savremeni pristupi inkluzivnom obrazovanju", Visoka škola strukovnih studija za vaspitače i poslovne informatičare, Sremska Mitrovica, 13 jun 2013., Knjiga rezimea (str.23), ISBN 978-86-7447-120-3

Korać, I. (2015). Kompetencije vaspitača za rad u inkluzivnom okruženju- doprinos stručnog usavršavanja. Usmeno saopštenje na 6. Međunarodnoj naučnoj konferenciji „Inkluzija u predškolskoj ustanovi i osnovnoj školi“, Sremska Mitrovica, Srbija.

Kovačević, N. (2015). Spremnost vaspitača za rad u inkluzivnom obrazovnom kontekstu. Usmeno saopštenje na 6. Međunarodnoj naučnoj konferenciji „Inkluzija u predškolskoj ustanovi i osnovnoj školi“, Sremska Mitrovica, Srbija. 
Latinović, I. (2014). Okvir za praćenje inkluzivnog obrazovanja u Srbiji. Beograd: Tim za socijalno uključivanje i smanjivanje siromaštva.

Lecavalier, L., Leone, S., \& Wiltz, J. (2006). The impact of behaviour problems on caregiver stress in young people with autism spectrum disorders. Journal of Intellectual Disability Research, 50(3), 172-183.

Mihić, I., Rajić, M. (2015). Usluge u lokalnoj zajednici za porodice dece sa smetnjama u razvoju: uloga predškolskih ustanova. U Kuburić i sar. (Ur.) Istraživanja u oblasti socijalnog rada, socijalne zaštite i socijalne politike. Novi Sad: Filozofski fakultet.

Nosek, B., Greenwald, A. G., \& Banaji, R. M. (2005). Understanding and using the Implicit Association Test: II. Method variables and construct validity. Personality and Social Psychology Bulletin, 31, 166-180.

Pavlović Breneselović, D. (2013). Kompetencije ili kompetentnost: različiti diskursi profesionalizma vaspitača. Vaspitanje i obrazovanje, 34(2), 57-68.

Radaković, I., Rajić, M., Mihić, I. i Mirković, V. (2016). Doživljaj vlastitih kompetencija za rad sa decom sa smetnjama u razvoju: perspektiva studenata Visoke škole za obrazovanje vaspitača i vaspitača u praksi. Usmeno saopštenje na IV Međunarodnoj naučnoj konferenciji "Specijalna edukacija i rehabilitacija - Rana intervencija" (14.10.-16.10.2016.). Beograd: Fakultet za specijalnu edukaciju i rehabiitaciju. ISSN: 0354-8759

Rajović, V., Jovanović, O. (2010). Profesionalno i privatno iskustvo sa osobama s posebnim potrebama i stavovi nastavnika redovnih škola prema inkluziji. Psihološka istraživanja, 13 (1), 91-106.

Robertson, K., Chamberlain, B., \& Kasari, C. (2003). General education teachers' relationships with included students with autism. Journal of Autism and developmental disorders, 33(2), 123-130.

Sakač, M., Marić, M. (2016). Dimenzije kvaliteta inkluzivnog rada vaspitača. Beogradska defektološka škola, 22 (2), 93-109.

Sheridan, S. (2007). Dimensions of pedagogical quality in preschool. International Journal of Early Years Education, 15(2), 197-217.

Sretenov, D. (2008). Kreiranje inkluzivnog vrtića- Deca ometena u razvoju u redovnoj predškolskoj ustanovi. Beograd: Centar za primenjenu psihologiju.

Stanisavljević-Petrović, Z. i Stančić, M. (2010). Stavovi i iskustva vaspitača o radu sa decom sa posebnim potrebama. Pedagogija, 62 (1), 70-79.

Stanković-Đorđević, M. (2007). Stavovi vaspitača o vaspitno-obrazovnom radu sa decom sa razvojnim smetnjama. Pedagogija, 62 (1), 70-79. 
Stančić, M., i Stanisavljević Petrović, Z. (2013). Mišljenje vaspitača o koristima od inkluzije i načinima njenog ostvarivanja. Specijalna edukacija $i$ rehabilitacija, 12(3). 353-369.

Stojanović, B. (2009). Повезивање теорије и праксе у припреми будућих васпитача. In M. Matti (ed.), Proceedings of the International Conference Promoting Teacher Education from Intake System to Teaching Practice (219-233). Jagodina: Faculty of Education, University of Kragujevac.

Subban, P., \& Sharma, U. (2006). Primary school teachers' perceptions of inclusive education in Victoria, Australia. International Journal of Special Education, 21(1), 42-52.

Tomić, K. i Milić, J. (2014). Dete sa autizmom u inkluzivnom vaspitnom kontekstu. Sinteze, 87-97.

Veljić, Č. (2010). Razlike u stvovima učitelja gradskih i seoskih škola o inkluzivnom obrazovanju. Beogradska defektološka škola. 3, 601-614.

Vujačić, M. (2009). Mogućnosti i ograničenja inkluzije dece sa teškoćama u razvoju u redovne osnovne škole. Neobjavljena doktorska disertacija. Novi Sad: Filozofski fakultet.

Žeželj, I., Jakšić, I., \& Jošić, S. (2015). How contact shapes implicit and explicit preferences: Attitudes toward Roma children in inclusive and non-inclusive environment. Journal of Applied Social Psychology, 45(5), 263-273.

Zavod za unapređivanje vaspitanja i obrazovanja - Katalog programa stalog stručnog usavršavanja nastavnika, vaspitača i stručnih saradnika za školsku 2016/2017. i 2017/2018.godinu Preuzeto 9.7.2017. sa http://katalog2016.zuov.rs/ 
